\section{Excretion and Hepatic Storage of 5,6-Dimethylbenziminazolyl Cobamide Coenzyme labelled with Cobalt-58}

BARKER et al. ${ }^{1,2}$ recently isolated a number of vitamin $\mathrm{B}_{12}$ derivatives from bacteria and demonstrated that they act as coenzymes in the conversion of glutamate to $\beta$-methylaspartate. Since the 5,6dimethylbenziminazolyl cobamide coenzyme (DCC) was found to occur in rabbit liver ${ }^{2}$, and to act as a co-factor in a rat enzyme system ${ }^{3}$, it is reasonable to assume that the coenzymes are the forms in which vitamin $B_{12}$ exists in the tissues and that the 'extrinsic factor' may largoly consist of DCC and similar compounds. Since we have previously been engaged in research on the turnover of vitamin $B_{12}$ (refs. 4 and 5), we thought it of interest to perform similar work on the turnover of radioactive DCC in man.

Four healthy student nurses who volunteered for the experiment were given an intragluteal injection of DCC labelled with cohalt-58. The preparation was kindly provided by the Squibb Institute for Medical Research, New Brunswick, New Jersey, and had a specific activity of about $1 \mu c$. per $\mu \mathrm{gm}$. The radioactive DCC was injected soon after its arrival from abroad and protected from light in order to minimize breakdown.

Three of the test subjects received a dose of $1 \mu \mathrm{gm}$. and one $0.75 \mu \mathrm{gm}$. in $1 \mathrm{ml}$. of physiological saline. The test subjects collected their excreta in one-day portions for 39 days (except on days off), and later frees only during the seventieth to seventy-ninth day following the injection. The samples of faces were incinerated at $600-800^{\circ} \mathrm{C}$. in porcelain cups in a coal furnace in the boiler room of the hospital. Recovery experimonts demonstrated that no loss of radio. activity occurred during this procedure. The urine samples were concentrated by evaporation. The ashes and the concentrates wero counted in a well-type scintillation counter together with appropriate standards, and the radioactivity was expressed as mugm. of the injected DCC.

Radioactivity counts were also taken over the liver area under standard conditions, once a day for the first 39 days, and once on the sixty-fifth day. The counts were corrected for radioactive decay.

The results of the excretion work are given in Table 1. It is seen that during the first fow days after the injection the urinary excretion was slightly elevated, but later on the excretion of radioactivity was remarkably constant. From the fifth day on, urinary and fæcal excretions wore about equal. The fraction of the total-body radioactivity lost por day was about 0.3 per cent or slightly less. This value corresponds to a biological half-life of about one year.

From the first day following the injection, relatively strong radioactivity was measured over the liver area, the counts ranging from 246 to 828 c.p.m. above the background ( 410 c.p.m.). Maximum counts were observed within the first 12 days. During the 65-day period when liver counts were taken, there was no clear-cut decrease in hepatic radioactivity. Thus the hepatic biological half-life must be long.

On the whole, the results obtained with radioactive DCC are very similar to those observed after administration of radioactive vitamin $B_{12}^{4,8-8}$. When radioactive DCC is injected there is possibly slightly less 'spill-over' of radioactivity into the urine in the days immediately following the injection. During later periods the excretion-rates and the total-body biological half-lives of the two compounds are very similar.

\section{WOLMAR NYBera} Mat's S SAarni

Department of Internal Medicine, The Central Hospital, Vasa.

RALPH GRÄSBECK

Clinical Laboratory Department, Maria Hospital,

Helsingfors, Finland.

${ }^{1}$ Barker, H. A., Smyth, R. D., Weissbach, H., Toohey, J. I., Ladd, J. N., and Volcani, B. t., J. Biol. Chem., 235, 480 (1960).

${ }^{2}$ Weissbach, H., Toohey, J., and Barker, HI. A., Proc. U.S. Nat. Acad. Sci., 45, 521 (1959).

${ }^{3}$ Gurnani, S., Mistry, S. P., and Johnson, B. C., Biochim. Biophys. Acta, 88, $187(1960)$.

4 Gräsbeck, R., Nyberg, W., and Reizenstein, P., Proc. Soc. Exp. Biol. Med., 97,780 (1958).

${ }^{5}$ Grăsbeck, R., Scand. J. Clin. and Lab. Invest., 11, 250 (1959).

' Cronkite, E. P., Henley, E., Driscoll, D. H., Meyer, L. M., Dohan, F. C., Rubini, J. R., and Wolins, W., Haematol. latina, 2, 265 (1959).

'Schloesser, L. L., Deshpande, P., and Schilling, R. H', Amer. Med. A8soc. Arch. Int. Med., 101, 306 (1958).

8 Glass, G. B. J., Haematol. latina, 2, 279 (1959).

\section{H/EMATOLOGY}

\section{Occurrence of Heparin in the Blood of Fish and its Prevention of the Clotting of Fish Plasma}

The property of the blood of fish to clot rapidly provides a means of protection from fatal hæmorrhage such as may follow injuries ${ }^{1}$. Sometimes in the same fish the blood clotting-time is known to differ markedly at two different phases of its life-cycle. In the prespawning phase when the fish is fully laden with reserves, blood clotting is almost instantaneous, whereas during the period of physiological stress which genorally follows spawning, clotting is slow and prolonged. Such variations in the coagulationtime have been attributed to some unknown factors which may involve a change in the chemistry of the blood of fishes ${ }^{2}$.

Table 1. Mean DaILY Excretion of Radoactivity

The radioactivity is expressed as m $\mu \mathrm{gm}$. of the injected preparation. $F$, fæces; $U$, urine; $\%$, sum of facal and urinary excretions expressed as percentage of the radioactivity estimated to be contained in the body at the time of excretion.

\begin{tabular}{|c|c|c|c|c|c|c|c|c|c|c|c|c|}
\hline $\begin{array}{c}\text { Case } \\
\text { Injected dose }\end{array}$ & $F$ & $1 \underset{U}{A}$ & $\%$ & $F$ & $\underset{1 \underset{V}{\mu \mathrm{gmm}} .}{\boldsymbol{B}}$ & $\%$ & $F$ & $\underset{U}{\stackrel{\mu \mathrm{gmm}}{U} .}$ & $\%$ & $F$ & $\begin{array}{c}D \\
0 \cdot 75 \mu \mathrm{gm} . \\
U\end{array}$ & $\%$ \\
\hline $\begin{array}{l}\text { 1st-4th day } \\
5 \text { th-39th day } \\
\text { 70th } 79 \text { th day }\end{array}$ & $\begin{array}{l}0 \cdot 4 \\
1.5 \\
1.3\end{array}$ & $\begin{array}{l}6 \cdot 2 \\
1 \cdot 1 \\
1 \cdot 0^{*}\end{array}$ & $\begin{array}{l}0.68 \\
0.28 \\
0.29\end{array}$ & $\begin{array}{l}2 \cdot 2 \\
1 \cdot 0 \\
1 \cdot 2\end{array}$ & $\begin{array}{l}5 \cdot 1 \\
1 \cdot 4 \\
1 \cdot 7 *\end{array}$ & $\begin{array}{l}0.75 \\
0.26 \\
0.38\end{array}$ & $\begin{array}{l}0 \cdot 3 \\
1 \cdot 0 \\
-\end{array}$ & $\begin{array}{l}5 \cdot 9 \\
1 \cdot 4 \\
-\end{array}$ & $\begin{array}{c}0.64 \\
0.26 \\
-\end{array}$ & $\begin{array}{l}0 \cdot 6 \\
1 \cdot 1 \\
0 \cdot 7\end{array}$ & $\begin{array}{l}3 \cdot 7 \\
1 \cdot 1 \\
0 \cdot 7^{*}\end{array}$ & $\begin{array}{l}0 \cdot 59 \\
0 \cdot 32 \\
0 \cdot 24\end{array}$ \\
\hline
\end{tabular}

* Because quantitative collection of urine for long periods is diffeult, the subjects collected only faces during this period, The urinary excretion was estimated on the assumption that the $U: F$ ratio was the same as during the preceding collection period, 